\title{
The use of Laser as a Treatment Modality for treatment of Impacted mandibular wisdom among patients of Taif University KSA
}

\author{
Mahitab Mahmoud Soliman*, Sherifa Moustafa Sabra** \\ *Professor of Oral \&Maxillofacial Surgery, Faculty of Medical Dentistry, Taif University, KSA. \\ **Assistant Professor of Microbiology, Faculty of Science, Taif University, KSA.
}

\begin{abstract}
The objective of this study was to assess the use of diode laser for surgical removal, and reducing the bacterial concentration around impacted lower wisdoms. Patients under study were 50 patients aged (19-35 years.), they were divided into two equal groups; the first was the control group; patients were subjected to conventional surgical treatment and the second was the study group; in which patients were treated with Diode Laser. Clinical follow up for post-operative pain, edema, and dry socket incidence, as well as bacterial isolation, and identification of Colony Forming Units (CFU), were done at the following post-operative periods; 1st, 3rd, 5th, and 7th days of operation. . Results showed marked reduction in the number of patients presenting with post-operative edema in the study group throughout the follow up period. Similarly the pain was much less in the lased group than the control group. The incidence of dry socket decreased in the study group if compared to the control one. Bacterial isolated species were facultative anaerobic as (Staph. aureus, CNS, Strept. viridans and mutans), while anaerobic were (Prevotella, Fusobacterium, Actinomyces, Bacteriods, and Lactobacillus species). The main growth degrees were 100, 80, 50, and 30\% for 1stgroup, and 100, 50, 30, and 20\% for 2ndgroup respectively. CFUs/ml resulted in 1stgroup as 3.2, 2.9, 2.3, and $1.9 x 104 / \mathrm{ml}$, but in 2ndgroup were 3.1, 2.4, 1.7, and $1.1 \times 104 / \mathrm{ml}$. While the CFU/ml differences between 1stand 2ndgroup were $0.1,0.5,0.6$, and 0.8 respectively. In conclusion: Laser treatment decreases post-operative discomfort, and aided reduction of CFU.
\end{abstract}

\section{Introduction:}

Diode lasers are very effective for soft tissue applications including incision, hemostasis and coagulation. Many advantages of the laser vs. the scalpel blade have been discussed in the literature. These include a bloodless operating field, minimal swelling, scarring, and much less or no postsurgical pain [1].The operculum covering the partially impacted molar may be superimposed by microbial infection, the mixed infection of gram positive and negative anaerobes may be the principal causative micro-organism for dental infections. These conditions cause limitation of the mouth opening and fluid accumulation in the interstitial area as a result of its transudation from injured blood vessels and fibrin obstruction of lymph drainage, destruction of the local tissues and severity of surgical intervention are in direct proportion to the presence of these postoperative squeals [2]. One of the most important and common complications following tooth extraction is dry socket (DS). This phenomenon occurs when a blood clot dissolves and consequently, the exposure of alveolar bone happens. DS is marked by severe and progressive pain, halitosis, regional lymphadenitis, and activity reduction.It is mostly prevalent in surgical extraction of mandibular third molar [3]. These complications reach their maximal at $12-48 \mathrm{~h}$ after surgery, but may completely resolve in 5-7 days [4]. In some cases, antibiotic prescription is empirical and based on the clinical condition of the patient, as a result, treatment is often inappropriate and leads to the development of bacterial resistance and even multiple resistances [5].Pericoronitis is an inflammatory and infectious condition that may accompany the clinical emergence of teeth. It generally does not arise in teeth that erupt normally; usually, it is seen in teeth that erupt very slowly or become impacted, and it most commonly affects the mandibular third molar. Once the follicle of the tooth communicates with the oral cavity, it is thought that bacterial ingress into the follicular space initiates the infection [6] due todifficulty of cleaning.Pericoronitis has an average of $8 \%$ incidence associated with wisdom teeth. However, this number includes single episodes of pericoronitis and a wisdom tooth with pericoronitis typically is only extracted if recurrent pericoronitis as in additional episodes occur.Many treatment modalities have been employed for the surgical removalof the third molar tooth, either using the ordinary scalpel blade, the crocodile gum punch, electro-surgery, or the dental Lasers [7].Odontogenic infections are produced by pericoronitis and periapical lesions, the origins of which are well known. Types of pathogens found in such lesions are also known, and the management strategies according to the phase of the odontogenic infection have been defined [8].Although the incidence of odontogenic infections has decreased in recent years as a result of 
improvements in orodental and general health care, it is well known that odontogenic infections are not caused by a single organism indeed; polymicrobial infections are frequently encountered, and in some cases up to 6 different species have been isolated.The treatment of odontogenic infections is based on two fundamental elements: mechanical/surgical management and antibiotic therapy [9]. When laser surgical procedures are carried out, the surface produced heals favorably as an open wound, without the need for sutures or surgical dressings. Studies have shown enhanced, faster and more comfortable wound healing when the diode laser is used in intra oral soft tissue lesion excisions [10].Pulsating semi-conductor Laser was used as apthous ulcer and stomatitis promoting healing agents due to its palliative effects to relief the symptoms of myofacial pains as well. [11].

Many of micro-organisms play no relevant pathogenic role, though their presence suggests that they could collaborate in the infectious process by supplying nutrients or growth factors, creating favorable $\mathrm{pH}$ conditions, or simply antagonizing other micro-organisms [12].Most of the indigenous anaerobic bacteria are part of the normal oral flora, tongue has been considered as the major source of commonsalivarybacteria, such as Gram-positive facultative Cocci [13].

Micro-organisms isolated from third impacted molars were 40\%Corynebacterium spp. 80\% Prevotelladenticola and 40\%Lactobacillus spp. Besides obligate anaerobicbacteria, Actinomyces spp. a predominantly facultativeanaerobic bacterium was isolated [14].Pericoronal pocketsrevealed that microorganisms are more often isolated from infected third molars, normal oral flora can also act as pathogens, and obligatory anaerobic Gramnegative species arenormally found in periodontal pockets and on various oral surfaces, such as Bacteriods. Same bacterial species can be found concomitantly because highly contaminated saliva flows freely between anatomically close sites. Strept.mutans, Lactobacillus and Prevotellaoralisi are the causative pathogens of acute and chronic pericoronitis [15]. The predominant micro-flora in pericoronitis anaerobic causing periodontitis, The isolates from pericoronitis are Strept. spp.,Actinomyces, Prevotella, Bacteriods, Fusobacterium, Campylobacter, Staph.Lactobacillus, Haemophilus. The micro-flora inpericoronitis appeared similar to that of diseased periodontal pockets. Most microbes causing pericoronitisare obligatory anaerobic bacteria [16]. Facultative anaerobic isolates from impacted molars were Strept. viridans, Corynebacterium spp. Haemophilus spp. Strept. mutans, CNS, Staph. aureus, Strept.pneumoniae, E. coli, Strept. pyogenes and Pseudomonas spp. with incidence of 90.5, 60.8, 56.8, 52.7, 45.9, 25.7, 23, $23,14.9$ and $10.8 \%$ and anaerobic isolates were Prevotellaspp.Fusobacterium spp., Actinomycesspp.,Bacteriods spp., Lactobacillus spp.,Campylobacter spp. andClostridium spp., had incidence of 98.6, 90.5, 81.1, 81.1, 70.3, 54 and $41.9 \%$ respectively [17].Soft tissue dental lasers have been introduced and employed successfully in a variety of dental applications. Since then laser was used as a surgical alternative treatment with several advantages including: ease of use, hemostasis (coagulation during cutting), providing aseptic field, reduced postoperative discomfort such as: edema, pain and dysfunction [18].Laser beams aid in the action of inactivation of bacterial cells accompanied by alterations of the ultra-structure of the cells, e.g. disordered cell wall structure; elongated cells connected together without separation of the daughter cells and different low density areas in the cytoplasm [19].

Anionic and neutral photosensitizers(PS) were found to bind efficiently to Grampositive bacteria to induce growth inhibition or killing by visible light, whereas Gramnegative bacteria were not killed [20]. There is a lethal effect of laser radiation on micro-organismsassociated with dental caries, periodontitis and perimplantitis [21].Light from both highpowerand lowpower Lasers was found to be effective in killing oralpathogenic bacteria sensitized with PS in vitro, thebactericidal effects of photo toxicity are wavelength ordose-dependent to eliminate periodontal pathogens, e.g.ActinobacillusActinomycesmcomitans, Fusobacteriumnucleatum, Porphyromonasgingivalis, Prevotellaintermedia, andStrept.sanguis [22].Diode laser has a wave length of (910-980 nm), which does not interact with dental hard tissues. Therefore, the Laser is an excellent soft tissue surgical tool, indicated for cutting and coagulating gingiva and oral mucosa, and for soft tissue curettage or sulcular debridement. It also has a bactericidal effect [23].The Diode Laser provides anonantibiotic solution. A.Actinomycesmcomitans has alsobeen found in atherosclerotic plaques, and there has been evidence to suggest that sub gingival A. Actinomycesmcomitans may be related to coronary heart disease.This makes it even more compelling to seek methods to control this aggressive pathogen [24].Laser soft tissue treatment for pericoronal infections has the effect on CFU which is clear in reducing bacterial loads. Due to its characteristics, as well as to other known advantages such as low cost and practicality, the diode laser has been compared to the other conventional methods [25].It has been subject of a diversity of studies intended to evaluate its potential in relation to its biocompatibility [26].

Aim of the research work: To compare treatment modalities of surgical flap incision for the removal of partially impacted mandibular $3^{\text {rd }}$ molar used in both groups. To determine the method of choice by comparing the intensity and the frequency of the post-operative symptoms, and to verify the use of diode laser as an anti- 
bacterial agent and its benefit in reducing the post-operative discomfort through reducing the bacterial count and the acceleration of healing.

\section{Materials and methods:}

This research was conducted at Quarwa Girl Campus of Taif University during the study year (2013). Random selection of patients complaining from recurrent episodes of pericoronitis around their mandibular third molar was done.Informed signed consents were obtained according to the World Declaration Statement of Helsinki [27], to approve their participation in the research study. The procedure was explained verbally and animatedly to the patients. The total number of the patients included in the study were 53 from those attending the University Outpatient Dental clinic .All patients presented with a partially erupted mandibular $3^{\text {rd }}$ molar defined according to the Pell and Gregory's classification as corresponding to class IA, IB, 2A,2B, diagnosed by the use of digital radiography.(Fig.1\&2).
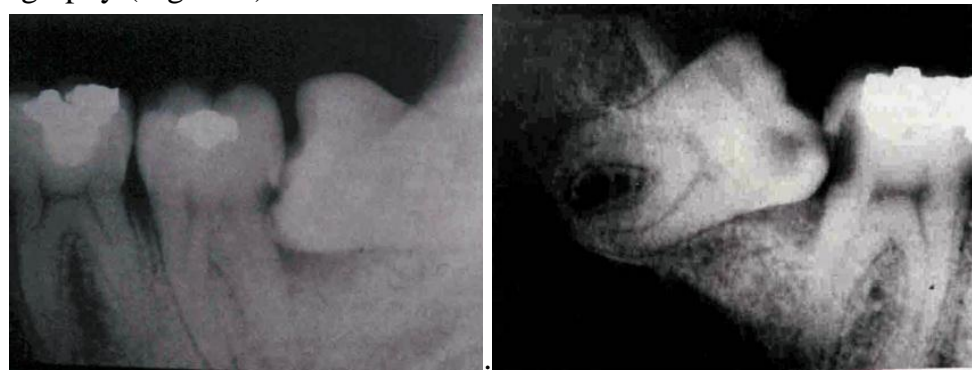

Figures (1\&2) : Periapical X-ray films showing class I position A impacted mandibular third molar

Laser Device Used: the Biolaseepic10 $10^{\mathrm{TM}}$ used for soft intra oral tissue .This type of, soft tissue diode laser, has one fiber optic cable that is threaded through a handle and used with the different operating tips. After each use, the used tip is discarded and another new tip is used for the next patient. Biolase requires no water or air connections and can be easily transferred between operatory. The wavelength $940 \pm 10 \mathrm{~nm}$, its maximum power output is $10 \mathrm{~W}$, power mode is either; continuous or pulse modulation. Fiber tips diameter; $200 \mu \mathrm{m}, 300 \mu \mathrm{m}$, $400 \mu \mathrm{m}$, pulse duration $0.01 \mathrm{~ms}-20 \mathrm{~ms}$, spot size $400 \mu \mathrm{m}$ (maximum in contact mode)

Surgical pattern: Patients were divided into two equal groups; $1^{\text {st }}$ group was the control group using conventional method (surgery scalpel by Bard Parker blade number 15), while $2^{\text {nd }}$ group acted as the study group; where the patients received irradiation method (Diode Laser Beams), which helped cutting of tissues while sterilizing and hemostasing, for incision of the mucoperioseal flap during surgery. Clinical assessment was made prior to treatment at the first visit. All patients were non pregnant, they were apparently healthy without any systemic diseases. All patients were not smoking. Patient and operating staff wore special diodelaser protective eye glasses. Highly reflective instruments or instruments with mirrored surfaces were avoided as there could be reflection of the laser beam. The diode laser was emitted in continuous mode, and was operated in a contact method using a flexible fiber optic hand piece with initiated tip. The Laser settings used were: fluent between 5 and $15 \mathrm{~J} / \mathrm{cm}^{2}$, pulse length between 20 and 50 milliseconds (ms), spot diameter of $2 \mathrm{~mm}$ and thermal relaxation times of 0.15 to 0.20 milliseconds. The power output at the end of the fiber was adjusted with power increase or power decrease touchpad until it measured from $1.2 \mathrm{~W}$ up till $2 \mathrm{~W}$. Local anesthesia was achieved using 1.8ml (2\% Mepevacaine hydrochloride/1:20,000 Levonordephrine). Surgical odontectomies were performed by only one, experienced surgeon and the duration of surgery was similar in the two investigated groups, being most frequently half an hour on average. Standardized surgical technique was performed by the same operator for both groups so as to unify the same operational conditions. Reflection of mucoperiosteal flap, luxation, then elevation of tooth and wound suturing, only two stitches were taken one distal to the second molar and one in the distal end of the incision and the socket was left opened. All patients of both groups received the same post-operative medications (anti-inflammatory only no antibiotics, and normal saline mouth wash were given) and the sutures were removed at the $7^{\text {th }}$ post-operative day.Follow up of both groups was established clinically and microbiologically, at the assigned post-operative intervals at $\left(1^{\text {st }}, 3^{\text {rd }}, 5^{\text {th }}\right.$, and $7^{\text {th }}$ post-operative days respectively). Clinical post-operative symptoms were recorded such as; the swelling or edema which was measured according to predetermined linear measuring points on the outside surface of the face in different anatomical planes [29].Intensity of pain was measured by the amount of pain through utilizing a Visual Analogue Scale (VAS). Operationally a VAS is usually a horizontal line, $100 \mathrm{~mm}$ in length, anchored by word descriptors at each end (no pain at one end till very severe pain on the other end).Patients were asked tomark on the line the point that they feel represents their perception of their current state. The VAS score is determined by measuring in millimeters from the left hand end of the line to the point that the patient marks[30],together with the non-eventful healing of the wound i.e. the incidence of dry socket. Follow upof both groups was performed for bacterial isolation and identification of Colony Forming Unit(CFU) as well. Results of both treatment methods under study were compared to assess the superior modality of treatment [31]. 


\section{Bacterial pattern:}

Bacterial isolation and identification: The specimens were collected using sterile paper tips. Specimens were collected intra operatively from pericoronal area, and were seeded onto culture media at that moment in the operating room. All collected specimens were collected intra and post-operatively. All specimens were placed immediately into an Eppendorff tube and kept deep-frozen $\left(-70^{\circ} \mathrm{C}\right)$ until sent for analysis in carbon dioxide ice. The samples were analyzed in Microbial Laboratory by standard methods [32].

Colony Forming Units (CFUs)/ml: Bacterial analysis for the Colony Forming Units(CFUs)/ml was performed. Specimens were collected intra operatively from pericoronal area, and in the follow up pre-mentioned days, with the help of paper points, and then they were transported in Robertson's cooked meat media to the microbiology laboratory within $1 \mathrm{hr}$. of collection. Specimens were labeled and processed immediately. CFU/ml of bacteria was calculated by: $y \times 10^{-\mathrm{d}} \times 1 / \mathrm{v}$ (where $\mathrm{d}=$ dilution plated, v=volume plated, and $\mathrm{y}=$ colony count on the plates, between 30 and 300) [33].

Data analysis: The data recorded during the study period (2013) were entered into Microsoft excel sheet. Data were summarized and analyzed using SPSS version 16 computer program. Data were analyzed using EpiInfo version 6statistical software and for further comparison Chi-square test was used at critical probability of $\mathrm{P}<0.05[34]$.

\section{Clinical results:}

\section{Results:}

From the total number of included patients (53) only (50) patients attended the surgical intervention and presented to the follow up periods, the other 3 patients didn't show up. All included patients are females (Girl's Branch), They underwent surgical removal for their mandibular third molar as it was indicated for extraction, due to its position and recurrent episodes of pericoronitis. The age ranged between (19-35years) with average 27 years old. In both groups, pain and swelling were most severe on $1^{\text {st }}$ and $3^{\text {rd }}$ postoperative days then decreased gradually through the subsequent evaluation periods to approximately reach the preoperative measures by the $7^{\text {th }}$ day.

Postoperative edema was differentiated into mild, moderate, severe and absence of edema (no edema), on the $1^{\text {st }}$ postoperative day the edema ranged from mild $13(52 \%)$ to moderate $11(44 \%)$ in the control group. While in the study group it ranged from absence of edema seen in 8pts.(32\%), mild in 12 (48\%), and moderate in $5 \mathrm{pts}(20 \%)$. On the $3^{\text {rd }}$ postoperative day severe edema was seen in 3 patients $(12 \%)$, moderate edema was seen in 17 patients $(68 \%)$, while mild edema was found in 5 patients $(20 \%)$ in the control group. On the contrary in the study group 10 patients represented without edema (40\%), 7 patients with mild edema (28\%), and 8 patients with moderate edema $(32 \%)$. On the $5^{\text {th }}$ postoperative day the number of patients presenting with severe edema in the control group was reduced to 1 patient (4\%), the moderate edema was reduced to 9 patients(36\%), the mild was increased to 14 patients $(56 \%)$, while only one patient had no edema at all (4\%). Regarding the study group the number of patients presenting without edema was increased to $12(48 \%)$, those with mild edema was increased to $11(44 \%)$, and the moderate was decreased to 2 patients $(8 \%)$. On the $7^{\text {th }}$ postoperative day there were 2 patients having no edema $2(8 \%), 17(68 \%)$ having mild edema and $6(24 \%)$ presented with moderate edema in the control group. Regarding the study group; the number of patients with no edema increased to $17(68 \%)$ while those of mild edema were $8(32 \%)$ patients.Edema peaked on 3rd day postoperatively in control group in which 20 patients $(80 \%)$ were having moderate to severe edema compared to 8 patients (32\%) having moderate edema in the study group. Regarding the pain at the1st postoperative day patients complaining of severe pain were $2(8 \%)$ only in the control group, moderate pain was found in $17(68 \%) ; 12(48 \%)$, at the $3^{\text {rd }}$ postoperative day still $2(8 \%)$ of control group had severe pain, moderate was in $11(44 \%) ; 6(24 \%)$, mild pain was seen in $12(48 \%) ; 17(68 \%)$, at $5^{\text {th }}$ postoperative day severe pain was not found in both groups, while the moderate pain was in $11(44 \%) ; 4(16 \%)$, mild $14(56 \%) ; 19(76 \%)$, and finally at the $7^{\text {th }}$ postoperative day patients presenting with moderate pain were $4(16 \%) ; 2(8 \%)$, mild $19(76 \%) ; 15(60 \%)$, while no pain was seen in $2(8 \%)$; $8(32 \%)$ in control and study groups respectively. Pain (using the visual analog scale) was worse on $1^{\text {st }}$ and $3^{\text {rd }}$ day and had decreased completely bythe $7^{\text {th }}$ day.Regarding the incidence of dry socket the results were as follows; at the $1^{\text {st }}$ postoperative day none $(0 \%)$; none $(0 \%)$, while at the $3^{\text {rd }}$ follow-up day were $2(8 \%)$; $1(4 \%)$, at $5^{\text {th }}$ postoperative day it was $2(8 \%) ; 1(4 \%)$ while at the $7^{\text {th }}$ postoperative day only $1(4 \%)$ in control group and none or $0(0 \%)$ in the study group. 
Table 1: Incidence of post-operative Edema for control and study groups

\begin{tabular}{|c|c|c|c|}
\hline \multirow{2}{*}{$\begin{array}{c}\text { Follow up } \\
\text { observation } \\
\text { days }\end{array}$} & \multirow[t]{2}{*}{$\begin{array}{c}\text { Edema } \\
\text { level }\end{array}$} & $\begin{array}{c}\text { Control group } \\
\text { No.=25 }\end{array}$ & $\begin{array}{l}\text { Study group } \\
\text { No.=25 }\end{array}$ \\
\hline & & Patient *No. (\%) & Patient No. (\%) \\
\hline \multirow[t]{4}{*}{$1^{\text {st }}$ day } & *Non. & $0(00 \%)$ & $8(32 \%)$ \\
\hline & *Mi. & $13(52 \%)$ & $12(48 \%)$ \\
\hline & *Mo. & $11(44 \%)$ & $5(20 \%)$ \\
\hline & $*$ Se. & $1(4 \%)$ & $0(00 \%)$ \\
\hline \multirow{4}{*}{$3^{\text {rd }}$ day } & Non. & $0(00 \%)$ & $10(40 \%)$ \\
\hline & Mi. & $5(20 \%)$ & $7(28 \%)$ \\
\hline & Mo. & $17(68 \%)$ & $8(32 \%)$ \\
\hline & Se. & $3(12 \%)$ & $0(00 \%)$ \\
\hline \multirow[t]{4}{*}{$5^{\text {th }}$ day } & Non. & $1(4 \%)$ & $12(48 \%)$ \\
\hline & Mi. & $14(56 \%)$ & $11(44 \%)$ \\
\hline & Mo. & $9(36 \%)$ & $2(8 \%)$ \\
\hline & Se. & $1(4 \%)$ & $0(00 \%)$ \\
\hline \multirow[t]{4}{*}{$7^{\text {th }}$ day } & Non. & $2(8 \%)$ & $17(68 \%)$ \\
\hline & Mi. & $17(68 \%)$ & $8(32 \%)$ \\
\hline & Mo. & $6(24 \%)$ & $0(00 \%)$ \\
\hline & Se. & $0(00 \%)$ & $0(00 \%)$ \\
\hline
\end{tabular}

*No.: Number, *Non.: None, *Mi.: Mild, *Mo.: Moderate, *Se.: severe

Table 2: Incidence of pain for control and study groups

\begin{tabular}{|c|c|c|c|}
\hline \multirow{2}{*}{$\begin{array}{l}\text { Follow up } \\
\text { observation } \\
\text { days }\end{array}$} & \multirow[b]{2}{*}{$\begin{array}{l}\text { Pain } \\
\text { level }\end{array}$} & Control group No. $=25$ & Study group No. $=25$ \\
\hline & & Patient $*$ No. $(\%)$ & Patient No. (\%) \\
\hline \multirow{4}{*}{$1^{\text {st }}$ day } & *No. & $0(00 \%)$ & $0(00 \%)$ \\
\hline & $*$ Mi. & $6(24 \%)$ & $13(52 \%)$ \\
\hline & *Mo. & $17(68 \%)$ & $12(48 \%)$ \\
\hline & $*$ Se. & $2(8 \%)$ & $0(00 \%)$ \\
\hline \multirow{4}{*}{$3^{\text {rd day }}$} & No. & $0(00 \%)$ & $2(8 \%)$ \\
\hline & Mi. & $12(48 \%)$ & $17(68 \%)$ \\
\hline & Mo. & $11(44 \%)$ & $6(24 \%)$ \\
\hline & Se. & $2(8 \%)$ & $0(00 \%)$ \\
\hline \multirow{4}{*}{$5^{\text {th }}$ day } & No. & $0(00 \%)$ & $2(8 \%)$ \\
\hline & Mi. & $14(56 \%)$ & $19(76 \%)$ \\
\hline & Mo. & $11(44 \%)$ & $4(16 \%)$ \\
\hline & Se. & $0(00 \%)$ & $0(00 \%)$ \\
\hline \multirow{4}{*}{$7^{\text {th }}$ day } & No. & $2(8 \%)$ & $8(32 \%)$ \\
\hline & Mi. & $19(76 \%)$ & $15(60 \%)$ \\
\hline & Mo. & $4(16 \%)$ & $2(8 \%)$ \\
\hline & Se. & $0(00 \%)$ & $0(00 \%)$ \\
\hline
\end{tabular}

*No.: Number, *No.: Non, *Mi.: Mild, *Mo.: Moderate, *Se.: severe

\section{Bacterial results:}

Table 3 and diagram 5 show the main bacterial growth degrees of pericoronal observation for $1^{\text {st }}$ and $2^{\text {nd }}$ groups understudy. The main isolates were facultative anaerobic as (Staph. aureus, CNS, Strept. viridans and mutans), while anaerobic were (Prevotella, Fusobacterium, Actinomyces, Bacteriods, and Lactobacillus species). The main growth degrees were $100,80,50$, and $30 \%$ for $1^{\text {st }}$ group, and $100,50,30$, and $20 \%$ for $2^{\text {nd }}$ group respectively.

Table 4 and diagram 6 show the main Colony Forming Units (CFUs)/ml of pericoronal observation for $1^{\text {st }}$ and $2^{\text {nd }}$ groups understudy. CFUs $/ \mathrm{ml}$ were starts as 3.2 and $3.1 \times 10^{4} / \mathrm{ml}$ in $1^{\text {st }}$ and $2^{\text {nd }}$ group, CFUs $/ \mathrm{ml}$ were in $1^{\text {st }}$ group as $3.2,2.9,2.3$, and $1.9 \times 10^{4} / \mathrm{ml}$, but in $2^{\text {nd }}$ group were $3.1,2.4,1.7$, and $1.1 \times 10^{4} / \mathrm{ml}$. While the $\mathrm{CFU} / \mathrm{ml}$ differences between $1^{\text {st }}$ and $2^{\text {nd }}$ group were $0.1,0.5,0.6$, and 0.8 respectively. 
The use of Laser as a Treatment Modality for treatment of Impacted mandibular wisdom among

Table 3:The main bacterial growth degrees of pericoronal observations for $1^{\text {st }}$ and $2^{\text {nd }}$ groups understudy

\begin{tabular}{|c|c|c|c|c|c|c|c|c|}
\hline \multirow{3}{*}{$\begin{array}{l}\text { Pericoronal } \\
\text { observations days }\end{array}$} & \multicolumn{8}{|c|}{ Observation days } \\
\hline & \multicolumn{2}{|c|}{$\mathbf{1}^{\text {st }}$ day } & \multicolumn{2}{|c|}{$3^{\text {rd }}$ day } & \multicolumn{2}{|c|}{$5^{\text {th }}$ day } & \multicolumn{2}{|c|}{$7^{\text {th }}$ day } \\
\hline & $\mathbf{1}^{\text {st }} * \mathbf{G}$. & $2^{\text {nd }} G$. & $\mathbf{1}^{\text {st }} \mathrm{G}$. & $2^{\text {nd }} G$. & $\mathbf{1}^{\text {st }} \mathrm{G}$. & $2^{\text {nd }} G$. & $\mathbf{1}^{\text {st }} \mathrm{G}$. & $2^{\text {nd }} G$. \\
\hline $\begin{array}{l}\text { Facultative } \\
\text { anaerobic: } \\
\text {-*Staph. aureus } \\
\text {-*CNS } \\
\text {-*Strept. viridans } \\
\text {-Strept. mutans }\end{array}$ & $\begin{array}{c}*+++++ \\
(100 \%)\end{array}$ & $\begin{array}{c}+++++ \\
(100 \%)\end{array}$ & $\begin{array}{l}*++++ \\
(80 \%)\end{array}$ & $\begin{array}{l}*+++ \\
(60 \%)\end{array}$ & $\begin{array}{c}+++ \\
(60 \%)\end{array}$ & $\begin{array}{c}*++ \\
(40 \%)\end{array}$ & $\begin{array}{c}++ \\
(40 \%)\end{array}$ & $\begin{array}{c}*_{+} \\
(20 \%)\end{array}$ \\
\hline $\begin{array}{l}\text { Anaerobic: } \\
\text {-Prevotella*spp. } \\
\text {-Fusobacterium spp. } \\
\text {-Actinomyces spp. } \\
\text {-Bacteriods spp. } \\
\text {-Lactobacillus spp. }\end{array}$ & $\begin{array}{c}+++++ \\
(100 \%)\end{array}$ & $\begin{array}{c}+++++ \\
(100 \%)\end{array}$ & $\begin{array}{l}++++ \\
(80 \%)\end{array}$ & $\begin{array}{c}++ \\
(40 \%)\end{array}$ & $\begin{array}{c}++ \\
(40 \%)\end{array}$ & $\begin{array}{c}+ \\
(20 \%)\end{array}$ & $\begin{array}{c}+ \\
(20 \%)\end{array}$ & $\begin{array}{c}+ \\
(20 \%)\end{array}$ \\
\hline $\begin{array}{l}\text { Total bacterial } \\
\text { growth }\end{array}$ & $\begin{array}{l}+++++ \\
(100 \%)\end{array}$ & $\begin{array}{l}+++++ \\
(100 \%)\end{array}$ & $\begin{array}{l}++++ \\
(80 \%)\end{array}$ & $\begin{array}{c}+++ \\
(50 \%)\end{array}$ & $\begin{array}{c}+++ \\
(50 \%)\end{array}$ & $\begin{array}{c}++ \\
(30 \%)\end{array}$ & $\begin{array}{c}++ \\
(30 \%)\end{array}$ & $\begin{array}{c}+ \\
(20 \%)\end{array}$ \\
\hline
\end{tabular}

*Staph.: Staphylococcal, * CNS: Coagulase Negative Staph., *Strept.: Streptococcal, *G: Group, $*_{+++++}=100 \%, *++++=80 \%, *+++=60 \%, *++=40 \%, *+=20 \%$.

Diagram 1: The main bacterial growth degrees of pericoronal observations for $1^{\text {st }}$ and $2^{\text {nd }}$ groups understudy

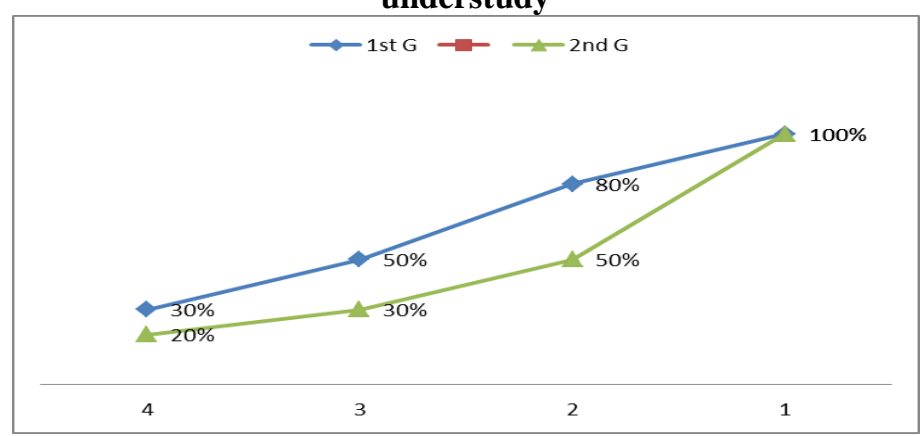

Table 4: The main Colony Forming Units (CFUs)/ml of pericoronal observations for $1^{\text {st }}$ and $2^{\text {nd }}$ groups understudy

\begin{tabular}{|c|c|c|c|c|c|c|c|c|}
\hline \multirow{3}{*}{$\begin{array}{l}\text { Pericoronal } \\
\text { observations } \\
\text { days }\end{array}$} & \multicolumn{8}{|c|}{ Observation days } \\
\hline & \multicolumn{2}{|c|}{$1^{\text {st }}$ day } & \multicolumn{2}{|c|}{$3^{\text {rd }}$ day } & \multicolumn{2}{|c|}{$5^{\text {th }}$ day } & \multicolumn{2}{|c|}{$7^{\text {th }}$ day } \\
\hline & $\mathbf{1}^{\text {st }} * \mathrm{G}$ & $2^{\text {nd }} G$. & $\mathbf{1}^{\text {st }} \mathrm{G}$. & $2^{\text {nd }} G$. & $\mathbf{1}^{\text {st }} \mathrm{G}$. & $2^{\text {nd }} G$. & $\mathbf{1}^{\text {st }} \mathrm{G}$. & $2^{\text {nd }} G$. \\
\hline$* \mathrm{CFU} / \mathrm{ml}$ & $3.2 \times 10^{4}$ & $3.1 \times 10^{4}$ & $2.9 \times 10^{4}$ & $2.4 \times 10^{4}$ & $2.3 \times 10^{4}$ & $1.7 \times 10^{4}$ & $1.9 \times 10^{4}$ & $1.1 \times 10^{4}$ \\
\hline Differences & \multicolumn{2}{|c|}{0.1} & \multicolumn{2}{|c|}{0.5} & \multicolumn{2}{|c|}{0.6} & \multicolumn{2}{|c|}{0.8} \\
\hline
\end{tabular}

*G: Group, *CFUlml: Colony Forming Units per $m l$

Diagram 2: The main Colony Forming Units (CFUs)/ml of pericoronal observations for $1^{\text {st }}$ and $2^{\text {nd }}$ groups understudy

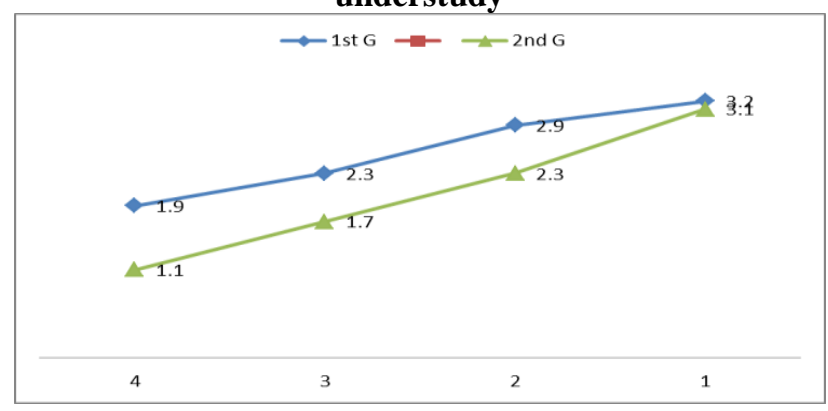




\section{Discussion:}

The main results of our study were that the laser assisted surgery resulted in significant improvement in swelling and pain and in reduction of dry socket incidence in the immediate postoperative period compared with control. The response rate to the study was high, indicating the high feasibility of using patient-centered outcome measures in oral surgery.Postoperative pain, edema, and dry socket(DS)are consequences of tissue injury and microbial infection during surgery[35].During oral surgery; damage caused to soft and hard tissues leads to an inflammatory reaction. This reaction can occur during and after surgical procedure following damage to the tissue. Tissue changes occur through endogenous biological mediators that are released from the blood cells and damaged tissue during inflammation. These include histamine, serotonin, kinin, and prostaglandin [36].Several trials have been used to prevent the occurrence of these complications by alteration in the operative surgical technique and reducing trauma as possible, so as to reduce the leakage of lymphand thereby the transudation of liquid. Also, non-steroidalanti-inflammatory drugs were administrated postoperatively as well as cold compresses and analgesics [37].Post-surgical pain and facial swelling affects the daily life of the patient. Many authors have advocated the use of low level laser therapy to limit postoperative pain, edema and dry socket due to their suppressive action on transudation, but few have made definitive recommendations supported by randomized clinical trials [38].No measures were taken to reduce postoperative symptoms in the aforementioned studies. The primary mechanisms are thought to involve suppression of leukocyte and macrophage accumulation at the site of inflammation, and prevention of prostaglandin formation through the disruption of the arachidonic acid cascade. The pain as a post-operative complication is the most common discomfort to occur after oral surgical intervention, in the present study the results showed that the pain was much less in the lased group if compared to the control one.The VAS scores for pain peaked on 1 st and $3^{\text {rd }}$ day of surgery. Thereis a close correspondence between the present findings for pain intensity and previous studies that have used VAS scores, even though these studies were conducted in different countries over a longperiod of time. Furthermore,they suggest that pain may not be the main factor for postoperative discomfort [39]. The results of the current study revealed that incidence rate of DS following surgical extraction of partially impacted mandibular molars at the $7^{\text {th }}$ postoperative day was $4 \%$.in the control group and $0 \%$ in the study group. This finding is in compliance with the incidence rate between 1 to $4 \%$ reported in some previous studies [40]. The use of soft tissue diode laser(STDL) hadattracted attention, as it induces primary biostimulation of cell metabolism and microcirculation, together with the photochemical, photoelectrical, and photo energetic accentuation [41].Thus it has a direct effect on lymph and blood vessels, with no adverse effects of irradiation, it is well known among oral surgeons that empirically, postoperative pain, edema and dry socket can always be expected after impacted lower third molar surgery. Operative trauma could be presumed to be fairly similar in all the study groups with regard to the need for tooth separation, drilling in bone, and duration of surgery. In the present study both groups received their medical and physical postoperative rescue therapy, it seems reasonable to attribute the favorable results in reduction of postoperative pain, edema or dry socket primarily to the effectiveness of the treatment methodology. Regarding the use of diode laser in oral surgery in respect of reducing postoperative sequeales, many studies proved its anti-edematous, analgesic and antimicrobial effects on experimental and clinical conditions [42]. STDL is believed to induce an increase in number and diameter of lymph vessels, with a simultaneous decrease of blood vessel permeability. This will consequently decrease prostaglandins and thus reduces these postoperative complications. The course of our investigation showed that the STDL therapy is more efficient in reducing average postoperative edema on the day of its peak occurrence. It exerted a significant anti-edematous effect on the 3rd postoperative day in comparison to the control group. The Diode laser therapy appeared to be non-invasive and without any adverse effect on the patients [43],but as we elongated the thermal relaxation time, no adverse thermal effects was encountered. The follow up on the $3 \mathrm{rd}$ postoperative day proved superiority of results of the laser group regarding the number of patients complaining of pain, and swelling and the formation of dry socket compared to the control group. On the $7^{\text {th }}$ post -operative day was notable in comparison to the results of the control group.It could be concluded that within the limitation of this study, Laser therapy is superior to the conventional surgical treatment in reducing postoperative edema after third molar surgery [44].

Therapeutic management usually involves a local surgical procedure and the prescription of antibiotics. The frequency of antibiotic resistant microorganisms is dependent on the populations and is related to the prescribing habits of practitioners in each country [45].The bactericidal effect of the Diode Laser was clearly evident by greater reduction of $\mathrm{CFUs} / \mathrm{ml}$ of obligate anaerobes in the test group than in the control group [46].Table 3 and diagram 1 show the main bacterial growth degrees of pericoronal observation for $1^{\text {st }}$ and $2^{\text {nd }}$ groups understudy. The main isolates were facultative anaerobic (Staph. aureus, CNS, Strept. viridans and mutans), while anaerobic were (Prevotella, Fusobacterium, Actinomyces, Bacteriods, and Lactobacillus species). The main growth degrees were 100, 80, 50, and $30 \%$ for $1^{\text {st }}$ group, and 100, 50, 30, and $20 \%$ for $2^{\text {nd }}$ group respectively.Micro-organisms isolated from third impacted molars were $40 \%$ Corynebacterium spp. $80 \%$ Prevotellaspp. and $40 \%$ Lactobacillus spp. a predominantly facultative anaerobic bacterium was isolated 
[14].Normal oral flora can also act as pathogens, and obligatory anaerobic Gram negative species are normally found in periodontal pockets and on various oral surfaces, such as Bacteriods [15]. The predominant micro-flora in pericoronitis is anaerobic causing periodontitis, are Strept.,Actinomyces, Prevotella,Bacteriods, Fusobacterium, Campylobacter, Staph. Lactobacillus, Haemophilus spp. The micro-flora in pericoronitis appeared similar to that of diseased periodontal pockets. Most microbes causing pericoronitis are obligatory anaerobic bacteria [16]. Facultative anaerobic isolates from impacted molars were Strept. viridans, Corynebacterium spp. Haemophilus spp. Strept. mutans, CNS, Staph. aureus, Strept. pneumoniae, E. coli, Strept. pyogenes and Pseudomonas spp. with incidence of 90.5, 60.8, 56.8, 52.7, 45.9, 25.7, 23, 23, 14.9 and $10.8 \%$ and anaerobic isolates were Prevotella spp. Fusobacterium spp. Actinomyces spp. Bacteriods spp. Lactobacillus spp. Campylobacter spp. and Clostridium spp. had incidence of 98.6, 90.5, 81.1, 81.1, 70.3, 54 and $41.9 \%$ respectively [17].Laser beams aid in the action of inactivation of bacterial cells accompanied by alterations of the ultra-structure of the cells, e.g. disordered cell wall structure; elongated cells connected together without separation of the daughter cells and different low density areas in the cytoplasm [19]. Table 4 and diagram 2 show the main Colony Forming Units $(\mathrm{CFUs}) / \mathrm{ml}$ of pericoronal observation for $1^{\text {st }}$ and $2^{\text {nd }}$ groups understudy. CFUs $/ \mathrm{ml}$ were starts as 3.2 and $3.1 \times 10^{4} / \mathrm{ml}$ in $1^{\text {st }}$ and $2^{\text {nd }}$ group, CFUs $/ \mathrm{ml}$ were in $1^{\text {st }}$ group as 3.2 , $2.9,2.3$, and $1.9 \times 10^{4} / \mathrm{ml}$, but in $2^{\text {nd }}$ group were $3.1,2.4,1.7$, and $1.1 \times 10^{4} / \mathrm{ml}$. While the CFU/ml differences between $1^{\text {st }}$ and $2^{\text {nd }}$ group were $0.1,0.5,0.6$, and 0.8 respectively [25].

\section{Conclusion:}

The diode laser as a modern therapeutic method proved to be a simple, elegant, and clean wayfor surgery without bleeding.It is far gentler than scalpel surgery; unlike electro surgery lasers do not require the placement of a grounding plate. Tissue separates gently and easily with the laser and hemostasis is achieved rapidly and there was minimal post-operative swelling. Diode Laser was well tolerated by the patients and it is more successful than conventional treatment methods. Diode Laser demonstrated a significant fast healing of soft tissue and decrease bacterial growth degrees and counts of CFUs/ml. Therefore, Diode Lasers treatment can form an integral part of oral surgery therapy in the future. However, further longitudinal studies are required to evaluate the long-term effects of Diode Laser on clinical as well as microbiological parameters. The bactericidal effect ofDiode Laser on specific micro-organisms and time taken for microbial re-colonization needs to be determined by further studies. Animal studies are required to provide an insight into the healing and bactericidal effects, with possible role for Diode Laser exposing its medical benefits.

\section{References:}

[1]. Gold V. (1994). Pulsed laser beam effects on gingival, J. Cline. Periodontal, 21:391-396.

[2]. Gonzalez-Santana H, Penarrocha-DiagoM,Guarinos-Carbo J, Balaguer-Martinez J. Painand inflammation in 41 patients following the placement of 131 dental implants. Med Oral Patol Oral Cir Bucal 2005: 10: 3: 258-263.(2005).

[3]. Hita-Iglesias P, Torres-Lagares D, Flores-Ruiz R, Magallanes-Abad N, Basallote-Gonzalez M, Gutierrez-Perez JL.(2008). Effectiveness of chlorhexidine gel versus chlorhexidine rinse in reducing alveolar osteitis in mandibular third molar surgery. J. Oral Maxillofac Surg., 66:441-446.

[4]. Eshghpour M, Moradi A, Nejat AH.(2013). Dry Socket following Tooth Extraction in an Iranian Dental Center: Incidence and Risk Factors. J Dent Mater Tech, 2(3): 86-91.

[5]. Khemaleelakul S., Baumgartner J. and Pruksakorn S. (2002).Identification of bacteria in acute endodontic infections and their antimicrobial susceptibility. Oral Surg Oral Med Oral Radiol Oral PatholEndod., 94:746-755.

[6]. Stathopoulos A. (2011). Cysts and tumors associated of a tooth division technique for the removal of impacted third molars: is prophylactic removal impacted teeth. Amer. J. Osthio. J. Oral Maxillo-facial; 69:405-408.

[7]. Ishii j., Fujita k. and Komari T. (2003). Laser surgery as a treatment of leuokoplakia .Oral Oncol., 39:759-769.

[8]. Leung W., Corbet E., Kan K., Lo E. and Liu J. (2005). A regimen of systematic periodontal care after removal of impacted mandibular third molars manages periodontal pockets associated with the mandibular second molars. J. Cline. Periodontal, 32:725731.

[9]. Brescó-Salinas M., Costa-Riu N., Berini-Aytés L. and Gay-Escoda C. (2006).Antibiotic susceptibility of the bacteria causing odontogenic infections. Med Oral Pathol. Oral. Cir.Buccal., 11:E70-E75.

[10]. Akoi M. and Takasaki L. (2008). Current status of clinical laser applications in periodontal therapy, General Dentistry, December:674-687.

[11]. Ribero A., Salles P., Da Silava T. and Mesquita R. (2010).A review of the non-surgical treatment of oral leukoplakia. Int. J. Dent., 186018 Epub.23. Surg., 69:405-408.

[12]. Sanjivan K. (2011). Evaluation and management of asymptomatic third molars: Watchful monitoring is a low-risk alternative to extraction. American Journal of Orthodontics and Dent. facial Orthopedics., 140:11-17.

[13]. Cugini M., Haffajee A., Smith C., Kent R. and Socransky S. (2000). The effect of scaling and root planning on the clinical and microbiological parameters of periodontal diseases: 12-month results. J. Cline. Periodontal, 27:30-36.

[14]. Jean S., Christophe M., Anne J., Michel C. and Martine B. (2003). Microbiology of mandibular third molar pericoronitis: Incidence of B-Lactamase-producing bacteria. Oral Sur. Oral Med. Oral Radio.and End odontology, 95:655-659.

[15]. Brescó-Salinas M., Costa-Riu N.,Berini-Aytés L. and Gay-Escoda C. (2006). Antibiotic susceptibility of the bacteria causing odontogenicinfections.Med. Oral Pathol. Oral Cir. Buccal, 11:E70-E75.

[16]. Ari R., Virpi L., Kirsti K., Anna P. and Jukka H. (2012).Periodontal bacteria in different sampling different sites of pericoronitis patients. Open J. Stomatology, 2:98-102.

[17]. Sherifa S. and Mahitab S. (2013).The Prevalence of Impacted Mandibular Wisdom with Associated Physical Signs and Microbial Infections among under Graduate Girls at Taif University, KSA. World Applied Sci. J., 21:21-29. 
[18]. Emre T., Ferda T., Robert S., Dolunay G. and Cem U. (2012). Comparative Evaluation of Antimicrobial Effects of Er:YAG, Diode, and CO2 Lasers on Titanium Discs: An Experimental Study. J. Oral and Maxillofacial Sur., 70:1064-1069.

[19]. Malik Z., Faraggi A. and Savion N. (1992).Ultra structural damage in photosensitized endothelial cells: dependence on hematoporphyrindelivery pathways. J. PhotochemPhotobiol. B., 14:359-368.

[20]. Minnock A., Vernon D., Schofield J., Griffiths J., Parish J. and Brown S. (1996). Photoinactivation of bacteria.Use of a cationic water-soluble zinc phthalocyanine to photo inactivate both Gram negative and Gram positive bacteria. J. Photochem. Photobiol. B., 32:159-164.

[21]. Dortbudak O., Haas R., Bernhart T. and Mailath-Pokorny G. (2001). Lethal photosensitization for decontamination of implant surfaces in the treatment of peri-implantitis. Cline. Oral Implants Res., 12:104-108.

[22]. Chan Y. and Lai C. (2003).Bactericidal effects of different laser wavelengths on periodontopathic germs in photodynamic therapy. Lasers Med. Sci., 18:51-55.

[23]. Ciancio M. (2006). Effect of a diode laser on ActinobacillusActinomycesmcomitans, Biological Therapies in Dentistry, November/December 22:no 3.

[24]. Spahr K. and Khuseyinova L. (2006). Periodontal infections and coronary heart disease: role of periodontal bacteria and importance of total pathogen burden in the Coronary Event and Periodontal Disease (CORODONT) study, Arch Intern Med., 166:554-559.

[25]. Schwarz F., Becker J., Sculean A., Berakdar M., Szathmari L. and Georg T. (2003). In vivo and in vitro effects of an Er:YAG laser, a GaAlAs diode laser, and scaling and root planning on periodontally diseased root surfaces: a comparative histologic study. Laser Surg. Med., 32:359-366.

[26]. Theodoro L., Haypek P. and Bachmann L. (2003). Effect of Er: YAG and diode laser irradiation on the root surface: morphological and thermal analysis. J. Periodontal, 74:838-843.

[27]. World Medical Association Declaration of Helsinki.(2008) Ethical Principles for Medical Research Involving Human Subjects. Adopted by the 18th WMA General Assembly, Helsinki, Finland, June 1964, and amended by the 59th WMA General Assembly, Seoul, October2008.)

[28]. Obiechina, A.E. 2003. Update in the, Annals of Ibadan lower impacted wisdom teeth in general dental Postgraduate Med., 1:40-44.

[29]. Carrillo SJ, Calatayud J, Manso JF, BarberiaE, Martinez MJ, Donado M.(1990) A randomized double-blind clinical trial on effectiveness of helium-neon laser in the prevention of pain, swelling and trismus after removal of impacted third molars. Int. Dent J., 40: $31-36$.

[30]. Wewers M.E. and Lowe N.K (1990). A critical review of visual analogue scales in measurement of clinical phenomena. Research in Nursing and Health,1990: 13, 227-236.

[31]. Vanessa T., Ana K., Janaita M., Marina C., Denise M., Claudio M. and Giorgio D. (2012). Clinical and microbiological evaluation of high intensity diode laser adjutant to non-surgical periodontal treatment: a 6-month clinical trial. Cline. Oral Invest., 9:703-707.

[32]. Matto J.,Saarela M. and Von B. (1996). Distribution and genetic analysis of oral Prevotella intermediate and Prevotellanigrescens.Oral. Micro. Immune., 11: 96-102.

[33]. Cai Z., Niladri C., Wenchao J., Conrad C., Jean-Philippe P. and Raymond M. (2011). Optimized digital counting colonies of clonogenic assays using Image software and customized macros: comparison with manual counting Int. J. of Radiation Bio., 87:1135-1146.

[34]. Coulombier D., Fagan R. Hathcock L. and Smith C. (2001).Epi Info 6 Version 6.04.A Word Processing, Database and Statistical Program for Public Health. Centers for Disease Control and Prevention, Atlanta, Delaware, USA.

[35]. Jovanovic G, Buric N, Kesic L (2004): Effect of low power laser on postoperative trismus. FactaUniversitatis Medicine and Biology .11: $3: 136-138$.

[36]. Shahzad AS, Irfanullah K, HumerK .(2011) Effectiveness of Submucosal Dexamethasone to Control Postoperative Pain \& Swelling in Apicectomy of Maxillary Anterior Teeth IJHS, Qassim University,5:2,156-165.

[37]. Tuner J, Hode L. Laser(1996) Therapy in Dentistry and Medicine. Sweden: Prima Books AD 1996: 50-52. (7).

[38]. Ustun Y, Erdogan O, Esen E, Karsli ED.(2003) Comparison of the effects of 2 doses of methylprednisolone on pain, swelling, and trismus after third molar surgery. Oral Surg. Oral Med Oral Pathol Oral RadiolEndod; 96: 535-539.

[39]. Iqbal MK, Kratchman SI, Guess GM, Karabucak B, Kim S.(2007) Microscopic periradicular surgery: perioperative predictors for postoperative clinical outcomes and quality of life assessment. J. Endod; 33: 239-244.

[40]. Noroozi AR, Philbert RF. 2013. Modern concepts in understanding and management of the "dry socket" syndrome: comprehensive review of the literature. Eshghpour et al. JDMT, Volume 2, Number 3, September 91

[41]. Barabash A, Tats A, Getling Z.(1995) Experience gained He-Ne laser therapy of patients with lichen planus at therapeutic stomatology clinic. Stom M, 1: 20-21.

[42]. Honmura 1., HonmuraA, Yanase M, Obata J, Haruki E. (1992) Therapeutic effects of GaAlAs diode laser irradiation on experimentally induced inflammation in rats. Lasers Surg Med 1992:12: 441-449.

[43]. Dalia A. Radwan1, Nermeen H. Mohammed, Ahmed A.Zaky.2010. Effectiveness of Low Power Laser Therapy and Betamethasone in Minimizing Postoperative Edema and Trismus after Third Molar Surgery: a Clinical TrialJournalof American Science,3: 136 -138.

[44]. Debobrato D., Stephanie R., Perry R. and Klokkevold B. (2012). A high-throughput comparative characterization of laser-induced soft tissue damage using 3D digital microscopy. Lasers in Med. Sci. Online publication, Jun: 6.

[45]. Yoichi T., Akira A., Koji M., Yasuo T., Shizuko I., Aristeo A., Frank S. and Yuichi I. (2012). Optimal Er:YAG laser irradiation parameters for debridement of micro-structured fixture surfaces of titanium dental implants. Lasers in Medical Sci. Online pub., 11:S1-S5.

[46]. Sneha R., Gokhale M., Ashvini M., Padhye M., Girish B., Sanjay A., Jain M.,Vikram P. and Sumanth S. (2012). A Comparative Evaluation of the Efficacy of Diode Laser as an Adjunct to Mechanical Debridement Versus Conventional Mechanical Debridement in Periodontal Flap Surgery: Cline. Micro. Study Photo. med. and Laser Sur., 30:598-603. 